\title{
マニラにおけるオープンスペースの現状とバーナムプランの比較分析
}

\section{Analysis and Comparison of Public Open Spaces of the Burnham Plan and the Present Manila}

ナバラ ナピラコーテ* 石川 幹子*

\section{Nappy Navarra Lacorte Mikiko ISHIKAWA}

Abstract: In the 1905 report submitted by Daniel Burnham to the Philippine Commission of the plan of Manila, one of the areas he focused on is the utilization of open spaces as areas for recreation. The Burnham plan identified different typologies of these public open spaces (POS) which were utilized for various functions and to respond to the demands of an emerging capital city and to anticipate the urbanization of the city. The public open spaces in the plan formed an interlinked system that shaped and defined the form of the city. The research looks at Manila after more than 100 years after the Burnham plan was proposed and evaluates the urban function of the different open spaces using the Functional Approach. It compares the original Burnham plan with the present POS using similar typologies, the system of open spaces developed and how their forms have been formed. Comparison of the Burnham plan and the present POS revealed significant reduction in most areas of the different typology of POS, except for POS located in traditional urban core. It was found that present POS with reduced areas have specialized and differentiated functions, manifesting the pressures of urbanization and lack of coherent policy on open spaces that shaped the urban spatial structure of Manila. From a grand design and extensive open spaces that characterized the City Beautiful Movement, the piecemeal development and management of the different open spaces of the present-day Manila presents a stark contrast to the original plan.

Keywords: Manila, Burnham, Public Open Space

キーワード：マニラ、バーナム、公共オープンスペース

\section{Introduction}

At present, the city of Manila is suffering the effects of rapid urbanization. Various environmental problems have risen, mostly attributed to population distribution and inability of various government bodies to provide infrastructure support to accommodate the growth of the city. ${ }^{1)}$ The continued urbanization has resulted to a city that lacks direction and coherence, neglecting in the process certain urban necessities that need to be addressed, mainly its public open spaces (POS).

A century before, with the vision to develop Manila into a premier capital city in Asia, The United States of America, sought the service of Daniel Burnham to design the masterplan of Manila. ${ }^{2)}$ The plan resembled (and preceded) the Chicago Plan with its wide boulevards and expansive public open spaces. ${ }^{3)}$ Being one of the main proponents of the City Beautiful Movement, Burnham emphasized the importance of large public open spaces. The City Beautiful Movement saw the provision of parks and open spaces as the panacea to the aftereffects of industrialization, such as pollution, urban congestion, public health issues, lack of utilities, and general lack of order.

Previous researches on the Burnham Plan ${ }^{4}$ have mainly focused on the analysis of the different urban forms that have evolved since the plan wassubmitted and subsequently implemented to a certain extent. Santiago (2003) noted that the Burnham plan had integrated the proposed POS with the existing open spaces, particularly in Intramuros. The plan provided linkages with the city center using different open spaces, creating an integrated historical core in the city of Manila. ${ }^{5)}$ On the other hand, Hines (1972) and Lico (2008) both looked at the Burnham plan as a means of enforcing the imperial ambition of the colonizer (United States of America) to the colony (Philippines). Interpreting the wide boulevards and extensive transportation networks that connect the areas of political, and economic importance as a means of achieving more political and

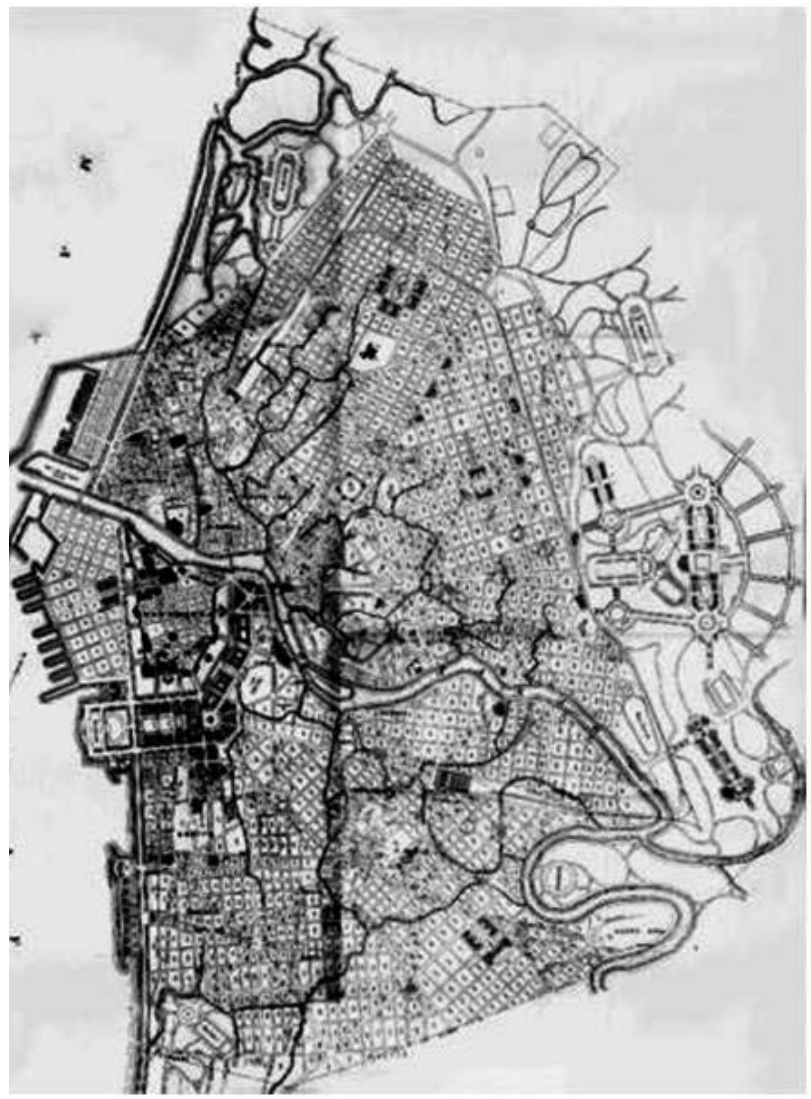

Figure- 1: Scanned Burnham Plan of Manila 


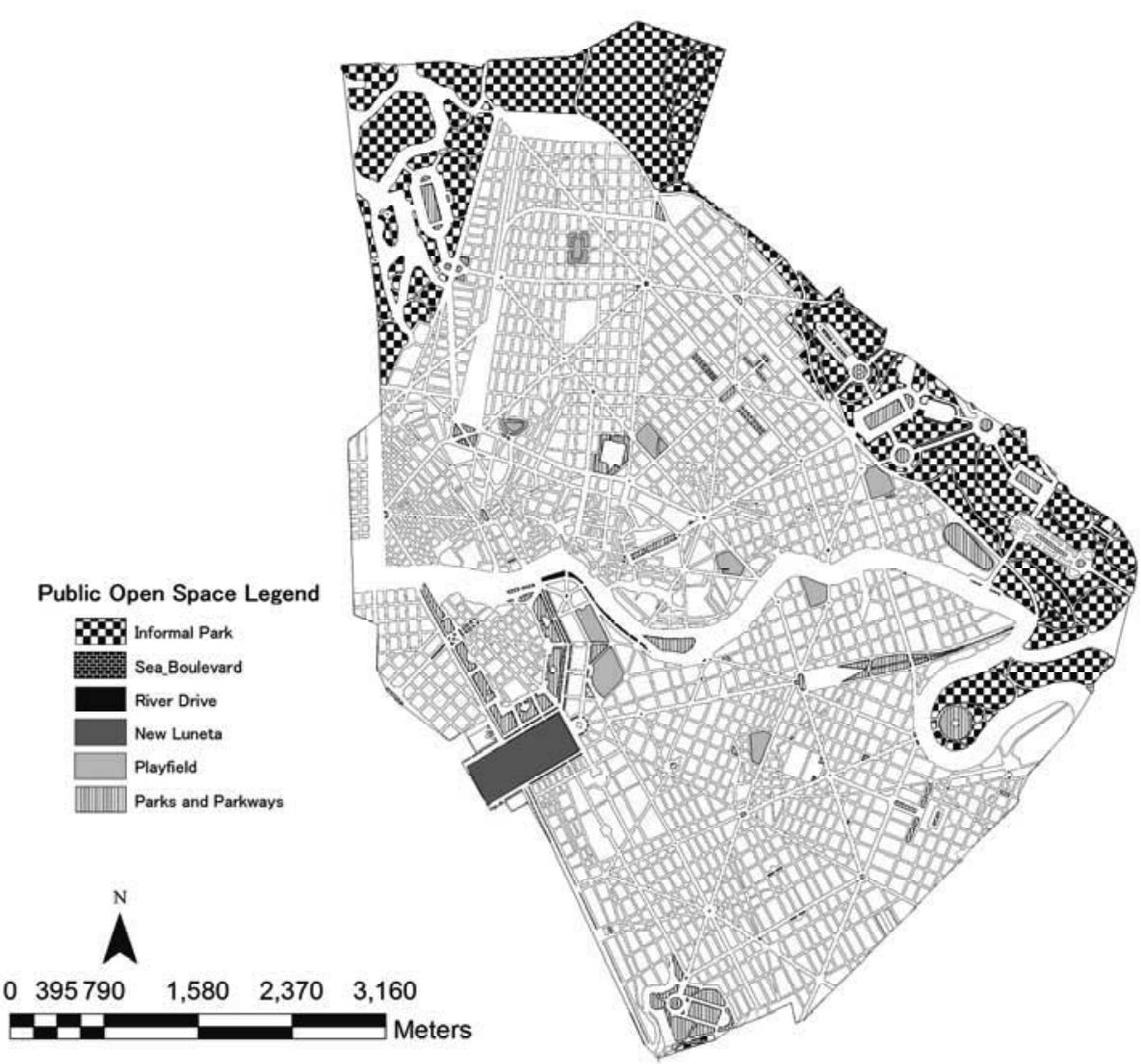

Figure- 2: POS of Burnham Plan of Manila
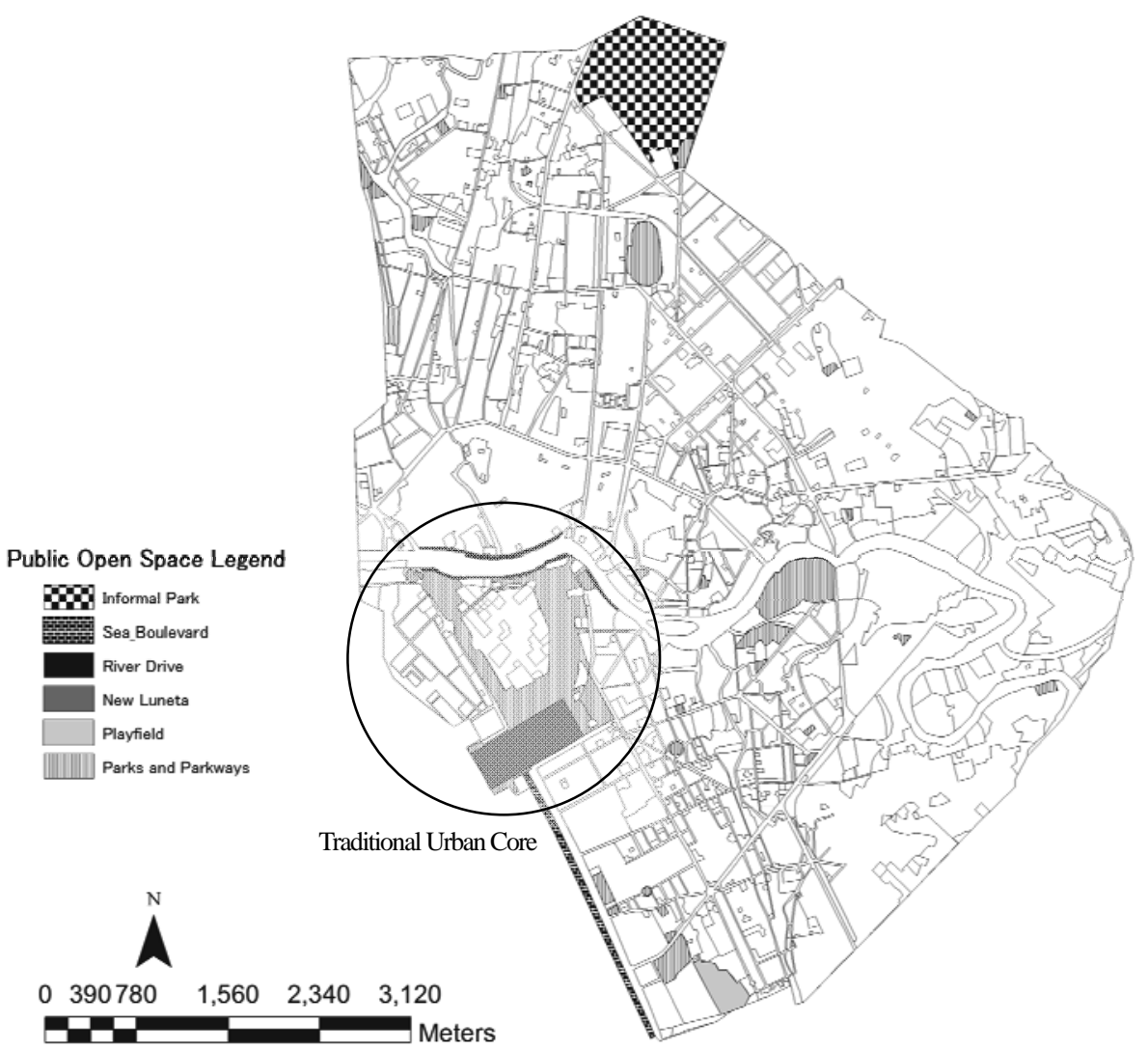

Figure- 3: POS of 2003 Land Use of Manila 
economic hegemony, it reinforced the ideal embodied in the ideology of the colonizer. These studies have contributed to putting the overall Burnham plan in the context of the urbanization of Manila, while research on the effects of the proposed POS to the present condition of the Manila's POS leaves a gap.

Some of these POS proposed in the plan of Burnham remain at present, some of them have evolved in different form and functions. However, many of the proposed public open spaces remain unrealized and or converted into non-functional definition of POS. The importance of these public open spaces in urban life has never been emphasized enough, especially for a developing country with a capital city that has a population of 1,660, $714(2007)^{6}$. Pressures of urbanization have resulted to piecemeal development of public open spaces, lack of adequate maintenance of existing POS, and continued threat of converting POS into other uses. As an important component in the urban environment, POS provides structure and form to the city, gives identity to different urban communities, maintain the balance of land use, provide spaces for recreation, preserves spaces with scenic and historic qualities, protect important ecological resources and natural systems. ${ }^{\text {7) }}$

The study aims to examine the urban condition of Manila, focusing on its public open spaces (POS) as to how the allocation of POS by the Burnham plan has resulted to their present condition. It has been observed that the POS, which forms the basic green infrastructure of the urban environment, suffers the effects of urbanization. To present the difference in the urban environment before Manila experienced rapid urbanization, an evaluation of the Burnham plan is conducted to present how this has differed to the present POS of Manila. The present condition of Manila's POS is evaluated using the typology of Burnham's open spaces and analyzed using the Functional Approach to determine how the shift from multi-functional spaces to specialized function affected the present POS, specifically their sizes.

\section{Methodology}

Public open spaces or POS are any land or pieces of land relatively free from any development purposely intended for public recreation, to hold events, and to facilitate environmental process. ${ }^{8)}$ Accessibility is mainly free and open to the public. However, in certain cases, certain fee may be charged for the upkeep and maintenance of the area. Other open spaces open to the public, which are actually privately owned, are not included since the provision of open spaces is included in the proposal of Burnham as part of the government's function.

The study involves the analysis and comparison of the Burnham Plan to the present condition of the Manila. The two plans are analyzed as to the distribution and function of the different public open spaces (POS). In his report, Burnham explained that the land use or zoning of the different built-up and open spaces is purposely not specified to allow flexibility in the implementation of the plan. He, however, identified several typologies of these open spaces, which he emphasized have definite functions in the city. His typologies of POS include: Playfields, Riverdrive, Sea Boulevard, Informal Park, New Luneta, and Parks and Parkways.

The difference between the present POS and of Burnham's proposal is analyzed in terms of Functional Approach, in which POS are evaluated as to their function. The approach espouses the idea that all open spaces serve certain functions, which are affected by the conditions of society. It offers a large-scale view of the different open spaces, in which open spaces have to be designated and planned since it assumes that the form of open spaces reflect the social and economic milieu. It posits that from a colonial period to its transition to becoming a more modern city, the function of public open spaces is becoming more specialized from being multi-functional space. It sees colonial open spaces as domains for the public, an extension of their homes and as spaces for social interaction. It favors flexibility of spaces, integrating vernacular practices with the colonial hegemony. However, as urban areas become more advanced, these POS are becoming more specialized, oftentimes subverted by the vehicular traffic in places formerly dominated by human-scaled and pedestrian spaces. The trend of the specialization of POS is due to the following: the size of the settlement, social contrast, and productivity."

To demonstrate the influence of the changes in the function of the POS during the Burnham Plan to the present condition of POS, the sizes of the different typologies of POS are analyzed. The data were presented in several tables to summarize the typology created by Burnham in his classification of the different open spaces he proposed in his plan of Manila. As public amenity, accessibility by most number of users is important since traffic indicates how functional the open spaces are with regard to their intended function. To compare the current state from the proposed plan of Burnham, the Burnham plan of Manila was geo-referenced to the existing Geographic Information System (GIS) database of Manila. Through this, quantitative comparative analysis was conducted between the proposed Burnham Plan and the present condition of POS. The open spaces of the Burnham plan and the 2003 plan are classified according to the typology and planning area as defined by Burnham. This is done to effectively compare the state of the POS from the two different periods based on sizes. The data of the 2003 conditions of POS was generated from the GIS data provided by the Metro Manila Earthquake Impact Reduction Study (MMEIRS). The data used is the Land Use Data of Manila in 2003. The data is updated with aid of aerial photographs and actual ocular field survey. The different POS were identified, classified and quantified to present comparable figures with that of the Burnham plan.

A field survey was conducted from February to April 2011 to validate the present conditions of the different POS of Manila through photo-documentation and to qualitatively assess the state of these different POS by analyzing their present function and usage, management, and degree of implementation after the Burnham Plan. The different POS were evaluated as to any significant difference in terms of their conditions since the database uses 2003 data using POS representative. POS representative are POS which are still existing, have maintained the function they were intended for, or have been modified. They were assessed according to their function in terms of being component to the urban structure. Further, to understand how these POS are being managed and to frame them according to the urban agenda set by the government, different overseeing agencies involved in the management of these POS were consulted. This was done to comprehend the relationship between diversification of function of POS and the consequent specialization of the overseeing agency. ${ }^{10)}$

\section{Result}

The POS in the Burnham plan of Manila can be classified into six major typologies based on their function. These typologies include: (1) Sea Boulevard, (2) River Drive, (3) New Luneta, (4) Parks and Parkways, (5) Play Fields, and (6) Informal Parks. The Sea Boulevard is basically a 250-foot wide parkway that connects the government main mall and the neighboring province of Cavite. It is a wide boulevard that has tramways, bridle path, plantation and broad sidewalks. Similarly, the River Drive is an esplanade that follows the form of the Pasig River, mainly for recreation and to ameliorate the tropical heat. 
The New Luneta was an expanded open space formerly known as Bagumbayan, which Burnham proposed to extend towards the Manila Bay to take advantage of the scenic panorama of the Manila Bay. This area is envisioned to become a large pleasure park that will play an important role in the civic activities and political exercise.

Scattered around the city are the Parks and Parkways, which are open spaces intended to provide "breather" in the more urbanized center of the city. The Play Fields are actually nine public resorts with facilities for both indoor and outdoor sports, leisure facilities, and social halls. These are strategically located around the city to afford all quarters equal opportunity to enjoy the facilities. On the other hand, the Informal Parks are a series of parks around the periphery of the city to contain further expansion of the city. This forms a parkway that allows continuous connections between parks while at the same time serve to house some of the government and semi-public facilities.

When geo-referenced to the existing Geographic Information System (GIS) database of Manila, the POS in the Burnham plan constitute a significant area of the total land area of Manila, which is 35,349,260 square meters. POS comprised more than 18 percent of the total land area, in which the rest is devoted to built-up areas and Others (roads, transportation lines, ports, and utility spaces). Among the POS significant typologies are classified as Informal Parks, which occupy 14 percent of the total area, and Parks and Parkways (2.61 percent), and Playfields (one percent). The result of the tabulation is summarized as follows:

Table- 1: Land Use Distribution of Burnham Plan of Manila

\begin{tabular}{|c|c|c|c|}
\hline LANDUSE & $\begin{array}{l}\text { AREA(sq. } \\
\text { Meters) }\end{array}$ & $\begin{array}{l}\text { Percentage } \\
\text { Share }\end{array}$ & ProposedFunction \\
\hline Playfields & 345,443 & 0.98 & $\begin{array}{l}\text { PublicResorts,Sports } \\
\text { Center,LeisureAreas }\end{array}$ \\
\hline RiverDive & 22,329 & 0.06 & $\begin{array}{l}\text { Espalanade, Recreation, } \\
\text { Micao-dimateCooling }\end{array}$ \\
\hline SeaBoulevard & 22,846 & 0.06 & $\begin{array}{l}\text { Parkway,Uiban } \\
\text { Connector,Boulevard }\end{array}$ \\
\hline Infomal Park & $4,944,820$ & 13.99 & $\begin{array}{l}\text { ParkNetwork,Parkway, } \\
\text { HouseGovemmentand } \\
\text { Semi-PublicFacilities }\end{array}$ \\
\hline NewLuneta & 320,873 & 0.91 & $\begin{array}{l}\text { Central Park, Pleasure } \\
\text { Park, VistaFraming, } \\
\text { Political Stage,Social } \\
\text { CongregationPoint, }\end{array}$ \\
\hline Built-UpArea & $14,301,877$ & 40.46 & \\
\hline $\begin{array}{l}\text { Parks and } \\
\text { Parkways }\end{array}$ & 921,127 & 2.61 & $\begin{array}{l}\text { Community Parks, } \\
\text { Community Center, } \\
\text { "Breathing"Space }\end{array}$ \\
\hline Others & $14,469,945$ & 40.93 & \\
\hline Total & $35,349,260$ & 100.00 & \\
\hline
\end{tabular}

The 2003 Land Use data of Manila shows the city in a remarkably different condition. The analysis area is similar to the planning area used in the Burnham plan to present a comparative scenario as to how different the present condition of POS of Manila. POS are smaller with only less than 10 percent (9.79) of the total land use, in which the built-up areas increased tremendously. Major clusters of POS are concentrated in the traditional urban core (see Figure 3), the central part of the city along the bisecting river (Malacanan Palace Park) and the northern part where the Manila North Cemetery is located. When analyzed within the planning area of Burnham, the Sea Boulevard has been realized. However the boulevard has been shortened, terminating within the political boundary of Manila.
Table- 2: Land Use Distribution of 2003 Land Use of Manila

\begin{tabular}{|c|c|c|c|}
\hline LANDUSE & AREA(sqMeters) & PercentageShare & PresentFunction \\
\hline Playfields & 110,647 & 0.31 & SportsFacility \\
\hline RiverDive & 69,831 & 0.20 & $\begin{array}{l}\text { Esplanade, } \\
\text { Miao-dimateCooling }\end{array}$ \\
\hline SeaBoulevard & 102,183 & 0.29 & Parkway,Boulevard \\
\hline Informal Park & $1,037,098$ & 2.93 & MemorialPark \\
\hline NewLumeta & 320,873 & 0.91 & $\begin{array}{l}\text { Central Park, Social } \\
\text { CongregationPoint, } \\
\text { Historical Landmark }\end{array}$ \\
\hline Built-UpArea & $27,892,564$ & 78.91 & \\
\hline $\begin{array}{l}\text { Parks and } \\
\text { Parkways }\end{array}$ & $1,819,068$ & 5.15 & $\begin{array}{l}\text { CommunityParks, } \\
\text { UibanMarkers, }\end{array}$ \\
\hline Others & 3,996,995 & 11.31 & \\
\hline Total & $35,349,259$ & 100.00 & \\
\hline
\end{tabular}

Comparing the Burnham Plan data with the Land Use of 2003 (Table 2), there is a substantial difference in the total available POS as built-up spaces rose to 80 percent of the total land use, leaving less than 10 percent to POS. There is a substantial decline in the area occupied by Informal Parks, which have been mainly overtaken by urbanization. Comparing the allocation of POS of the Burnham Plan and the 2003 Land Use almost all of the areas of POS declined, except for the Parks and Parkways. However upon closer evaluation, it was revealed that many of these spaces classified as Parks Parkways do not serve their function and or in conditions unfit for recreational use. There is a slight increase in area for Sea Boulevard, which can be attributed to the reclamation of some parts of the Manila Bay to make way for the esplanade and the continuous development of river walk, along the Pasig River. On the other hand, there is no remarkable difference in the size of the (New) Luneta since its boundary has been retained and there is a continuing effort to maintain the (New) Luneta (or more popularly known now as Rizal Park), having been declared as a national park and historic landmark.

The term Others, which was used to classify areas with undefined or non-specific function, most often referred to Boulevards and Transportation Facilities (train network, roads, etc.) in the Burnham Plan. Although it could have been classified as Parks and Parkways, Burnham did not specify certain street networks as spaces for public recreation. However in the process of the evaluation, several POS have emerged which are not encompassed by the classification of Burnham. The typology "Others" was also used to classify spaces which are remnants of previous land use but have become open spaces. These spaces include the former Smokey Mountain, which is basically a hill of decomposing garbage that have been vegetated, a water treatment plant, and other neglected spaces. In terms of definition of POS, these spaces are limited in terms of accessibility since most of these areas are restricted from public use and currently do not offer any recreational use.

Of the nine playfields proposed by Burnham, only one has been realized. This playfield (Rizal Sports Stadium), is the only one that is functional as a sports facility. However, unlike Burnham's vision of a publicly accessible facility, the Rizal Sports Stadium is only open for use by people authorized by the Philippine Sports Commission, which oversee the facility. Similarly, the Informal Parks, which constituted a sizable area in the proposed plan of Burnham, is significantly smaller and what remains is the Manila North Cemetery.

Comparing the percentage of the different land uses and POS of the 


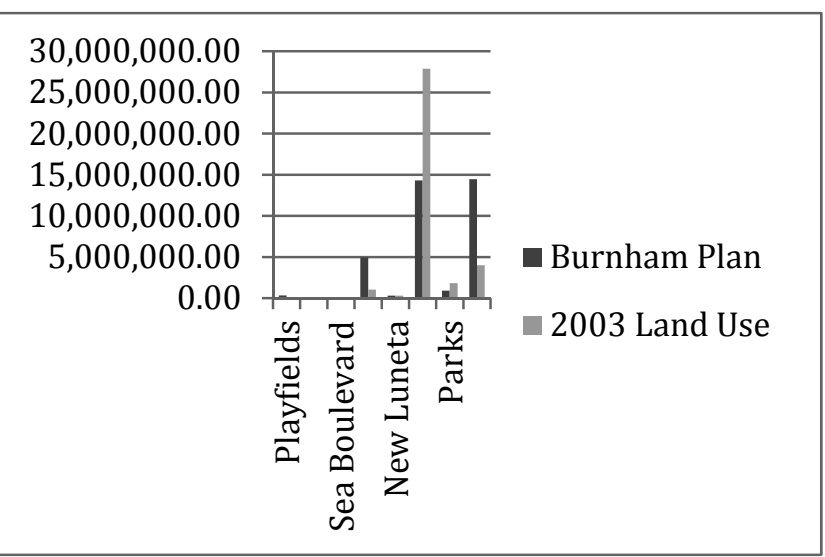

Figure- 4: Land Use Comparison of Burnham Plan and 2003 Land Use

Burnham plan of Manila and 100 years after the implementation of the plan will present a vastly different scenario. The built-up area has dramatically increased from the proposed 41 percent of the total land area, to 79 percent by 2003. On the other hand, Others have decreased from 41percent in the Burnham Plan to only 11 percent in 2003. This could be due to the conversion of the expansive boulevards and promenades proposed to various residential, commercial and industrial uses. To show comparison between the allocation of areas of the different typologies used by Burnham of the proposed Burnham plan and the present condition, Figure 4 illustrates the difference in area of the different typologies and land uses. With the population of Manila in 1903 at 223,029, the POS per capita according to the Burnham Plan would have been 29.49 sq. meters, compared to only 2.08 sq. meters by present standard. This smaller area of POS mean smaller recreational areas for individual residents of more urbanized present Manila.

\section{Discussion}

Urbanization is especially intensified in areas with concentration of proposed POS. This is especially true in the case of the Informal Parks which have not been realized due to its proximity to the city center, where urban activities are concentrated. This is the case of urbanization experienced by the city which has seen the conversion of many of its open spaces into amenity areas, like its esteros, riverbanks, floodplains into places of habitation and more commercial-oriented activities, and densification of human population around these open spaces.

Analyzing the different POS according to the Functional Approach, emphasized that urban designs especially applied to developing countries with historic environment often lose the original intended function of the open spaces. This could probably provide explanation on the preservation of (New) Luneta and its adjacent open spaces. Luneta, being a popular tourist destination, makes it an ideal space for economic activities, while functioning as a political space with its capacity to draw audiences from various socio-economic background. Contrast of different social groups seeking to find common spaces has led to the specialization of Luneta and the consequent preservation of its original function. As to continued specialization of function of various POS, the Functional Approach provides several parameters: size of settlement, social contrast, and productivity. The population of the city of Manila has grown tremendously from being a settlement along the mouth of the Pasig River that runs across the alluvial plain. The population increase created pressure to the different urban spaces, particularly POS, inevitably for the provision of various urban amenities and function. Alongside the increase in size of settlement is the diversification and stratification of urban classes, displaying the contrast between different classes of people. This particularization of interests and affluence had also resulted to increased demands for POS that cater to specific requirements of various social classes. This could also lead or have been the result of the differentiation of the mode of production in which various POS have been appropriated

Table- 3: Summary of Present Condition of POS and Managing Agency

\begin{tabular}{|c|c|c|c|c|c|}
\hline Public Open Space & Burnham Proposal & $\begin{array}{l}\text { Representative } \\
\text { POS }\end{array}$ & Present Condition & Accessibility & ManagingAgency \\
\hline Sea Boulevard & $\begin{array}{l}\text { Esplanader for } \\
\text { recreation; stretches } \\
\text { from New Luneta to } \\
\text { Cavite }\end{array}$ & Manila Baywalk & Achieved and Existing & Free Access & City of Manila \\
\hline River Drive & $\begin{array}{l}\text { Shaded drive along } \\
\text { the banks of Pasig } \\
\text { River }\end{array}$ & Muelle del Rio & Achieved and Altered & $\begin{array}{l}\text { Free Access limited to } \\
\text { opened portions }\end{array}$ & $\begin{array}{l}\text { Pasig River Rehabilitation } \\
\text { Commission }\end{array}$ \\
\hline New Luneta & Government center & Rizal Park & $\begin{array}{l}\text { Achieved and } \\
\text { Existing, currently } \\
\text { under proposal for } \\
\text { re-development }\end{array}$ & $\begin{array}{l}\text { Free Access to the main } \\
\text { park, minimal entrance } \\
\text { fee for other gardens }\end{array}$ & $\begin{array}{l}\text { National Parks Development Comm } \\
\text { Department of Tourism }\end{array}$ \\
\hline Parks and Parkways & $\begin{array}{l}\text { Minor open spaces for } \\
\text { recreation and as } \\
\text { architectural accessory }\end{array}$ & Manila Zoo & $\begin{array}{l}\text { Existing but not in } \\
\text { Burnham Plan }\end{array}$ & $\begin{array}{l}\text { Free Access to parks } \\
\text { administered by the city } \\
\text { government, except for } \\
\text { Manila Zoo; } \\
\text { NPDC-managed park } \\
\text { requires minimal } \\
\text { entrance fee }\end{array}$ & $\begin{array}{l}\text { City of Manila, Local Government } \\
\text { Units, NPDC }\end{array}$ \\
\hline Play Fields & $\begin{array}{l}\text { Public facilities with } \\
\text { amenities for } \\
\text { recreation and sports }\end{array}$ & $\begin{array}{l}\text { Rizal Sports } \\
\text { Complex }\end{array}$ & $\begin{array}{l}\text { Achieved and existing, } \\
\text { but not in original } \\
\text { location in Burnham } \\
\text { Plan }\end{array}$ & $\begin{array}{l}\text { Access restricted to } \\
\text { PSC-authorized persons }\end{array}$ & Philippine Sports Commission \\
\hline Informal Parks & $\begin{array}{l}\text { Parkway that connects } \\
\text { parks along the } \\
\text { outskirts of the city }\end{array}$ & $\begin{array}{l}\text { Manila North } \\
\text { Cemetery }\end{array}$ & Achieved and Existing & $\begin{array}{l}\text { Access restricted by } \\
\text { appointment or to lot } \\
\text { owners }\end{array}$ & City of Manila \\
\hline Others & $\begin{array}{l}\text { Boulevards, nature } \\
\text { park along waterways } \\
\text { for recreation }\end{array}$ & Taft Avenue & $\begin{array}{l}\text { Achieved and not } \\
\text { existing, converted into } \\
\text { vehicular thoroughfare }\end{array}$ & Free Access & $\begin{array}{l}\text { Department of Public Works and } \\
\text { Highways }\end{array}$ \\
\hline
\end{tabular}


to various uses, specifically with the rise of the tourism industry. Some areas have been designated as tourism-oriented spaces, which could negate the other functions (ecological process, social spaces, and others) and favor economic value of the space.

The condition of POS in the traditional urban core demonstrates how the former colonial capital was able to maintain its POS structure. There is a relative openness in the area where Luneta/Rizal Park, Intramuros, and the proposed government center is located. These areas were the focus of intensive implementation of the early years of the Burnham Plan. In contrast, other POS in the peripheral areas of the boundary have virtuallyt vanished, except for the Manila North Cemetery, which was also constructed during the early years of the American occupation. Many POS in non-traditional urban core have been converted into other functions, or have been supplanted by urban development.

In terms of the relationship of function and sizes, it can be noted that areas which have been able to maintain the multi-functional uses of POS were able to maintain their sizes (New Luneta), or even increased their sizes (Sea Boulevard River Drive, and Parks and Parkways). On the other hand areas which have shifted to more specialized function have become severely smaller (Playfields and Informal Parks).

In terms of implementation and management of the different POS, several agencies are managing different POS and that there is no masterplan or agendum regarding open spaces, and no coordination observed among the managing agencies. The managing agency has been included to present the reality of the effect of implementation to the overall urban structure of the city of Manila, in which the multitude of implementing agencies have not developed a coherent spatial structure of the urban environment. These different agencies maintain specialized function serving their specific purpose, which follow the specialization of function of POS as well as the managing agency that oversee their maintenance. Different government bodies are managing different open spaces, ranging from the smallest local government unit to the national government. The national government, with the Department of Tourism as the lead agency manages (New) Luneta and Paco Park, both spaces with historical significance. On the other hand, with their different thrust and mandate, the Philippine Sports Commission and the Pasig River Rehabilitation Commission have continued to proceed with their development of their respective POS without reference to a system of POS. The local units of the city government of Manila manage most of the Parks, such as plazas, circles, and community parks .

\section{Conclusion}

The plan of Burnham of Manila presents an opportunity for a logical urban spatial structure shaped by public open spaces. However, a century has passed and there is a vast difference from what has been the intended form and function of the different open spaces. The substantially smaller open space components of the urban environment has resulted to an urban environment overridden by urbanization. Various factors as identified by the Functional Approach have contributed to the forms and functions of the present POS. The agglomeration and overlapping of functions of multi-functional POS have resulted to significantly larger open spaces, while more specialized and, oftentimes, POS that emphasized less on social connection, led to more fragmented and reduced areas of POS. The proximity of the different open spaces to the traditional urban core has affected the preservation of most of these spaces while those found in the periphery have not been realized and were not able to serve their function of containing urbanization. On the other hand, diversification of the function of open spaces, particularly in the case of POS has resulted to the preservation of its borders, plus the fact that it has the support of the national government. POS that are under the management of the national government have been able to maintain its form in the context of urban structure. However, the function has changed with regard to its original use as specialization led to more productivity-oriented activities. Urbanization has also resulted the need to expand the definition of public open spaces, which have been linked to the concept of accessibility and recreation.

\section{Acknowledgment}

Appreciation is extended to people and organizations from different government agencies and private libraries that helped the authors in writing this paper: The Manila City Hall, the University of the Philippines College of Architecture, the Ateneo de Manila University Rizal Library, the Lopez Museum and Library and L.Archt. Paulo Alcazaren. Special mention to the Ishikawa Laboratory members who helped in the completion of the paper: Negishi Yuta, Takatori Chika, Baba Hiroki, Akiko Iida, Yuki Hiruta, and Katagiri Yukiko.

\section{Notes and References}

1) Ohmachi,T. (2002) Ending the Cycle of Environmental Deterioration. In Metro Manila: In search of a sustainable future.(T. Ohmachi, E. Roman ed.) pp. 3-9, University of the Philippines Press, Quezon City. (in English) ${ }^{2)}$ Hines, T.S. (1972) The imperial façade: Daniel Burnham and American architectural planning in the Philippines. In Pacific Historical Review, Vol. 41 No.1 University of California Press, 33-53 (in English)

${ }^{3)}$ Lico, G. (2008) Arkitekturang Filipino. The University of the Philippines Press, Quezon City. pp. 243-250 (in English)

4) Plan of proposed improvements (1905). In United States Philippine Commission. Annual Report of the Philippine Commission, Bureau of Insular Affairs, War Department. Government Printing Office: Washington, D.C.

5) Santiago, A.M. (2003) The restoration of historic Intramuros: a case study in plan implementation. School of Urban and Regional Planning University of the Philippines and UP Planning and Development Research Foundation, Inc. pp. 50-54 (in English)

${ }^{6}$ http://www.citypopulation.de/Philippines-MetroManila.html.

${ }^{7)}$ Quoted from Northeastern Illinois Metropolitan Area Planning Commission. Open Space in Northern Illinois: Technical Report. No. 2 Chicago. In Rye, RD.S. (1997) Open Space Planning for Quezon City. In Philippine Planning Journal 29 (1), pp. 25-51.School of Urban and Regional Planning, Quezon City. (in English)

8) Carmona M., Heath, T., Oc, T., Tiesdell, S. (2003) Public places urban spaces: dimensions of urban design. Architectural Press. London. p.188 (in English)

9) Pozo, A.G. (1979) Public Open Spaces: Flexibility of their uses in historic and vernacular environments.

www.international .icomos.org/monumentum/vol18-19_18.pdf. 1979.(in English)

${ }^{10)}$ The POS and their corresponding managing agencies can be found in the official government website of the city of Manila http://www.manila.gov.ph while laws that stipulate the jurisdiction of various national agencies can be accessed www.chanrobles.com or www.lawphil.net 